\title{
Effect of kinematic viscosity variation with blended-oil biodiesel on engine performance and exhaust emission in a power tiller engine
}

\author{
Duk Gam Woo', Tae Han $\mathrm{Kim}^{2+}$ \\ ${ }^{1}$ Research Faculty of Agriculture, Hokkaido University, Sapporo, 060 - 8589, Japan \\ ${ }^{2}$ Department of Bio-industrial Machinery Engineering, Kyungpook National University, Daegu, 41566, Republic of Korea
}

\begin{abstract}
The optimum conditions for producing biodiesel by combining beef tallow, a waste resource with high saturated fatty acid content, and soybean oil, which has high unsaturated fatty acid content, were investigated. Furthermore, the kinematic viscosity reduction effects of biodiesel by using heating and ultrasonic irradiation were verified, and their impacts on engine performance and exhaust emissions were evaluated. The result shows that the optimum production conditions are a blend ratio of TASO3 (soybean oil to tallow blend ratio of 7:3) and a methanol to oil molar ratio of 12:1. Kinematic viscosity reduction experiment results showed that the kinematic viscosity reduction effects of ultrasonic irradiation and heating were similar, but the heating device is considered more effective because it is simpler and cheaper than the ultrasonic device. Experiment results on output performance and exhaust performance showed that the engine performance and exhaust performance of the fuel with reduced kinematic viscosity were higher than those of the untreated fuel. However, the output of biodiesel was lower than those of conventional diesel (CD) due to the low calorific value of biodiesel; the $\mathrm{NO}_{x}$ and $\mathrm{CO}_{2}$ emissions of biodiesel were higher than those of $\mathrm{CD}$, but the $\mathrm{CO}$ and $\mathrm{HC}$ emissions of biodiesel were lower.
\end{abstract}

Keywords: Brake-specific fuel consumption, Blended oils, Biodiesel, Exhaust emissions, Kinematic viscosity, Tallow

\section{Introduction}

Fossil fuels are currently the most important energy source, accounting for about $80 \%$ of all energy sources of the world [1]. However, global climate change, such as global warming and fine dusts caused by the indiscriminate use of fossil fuels, is threatening the human race [2]. Moreover, fossil fuels are limited and will be exhausted in the near future [3]. Consequently, active research to develop alternate energy sources is underway around the world. Among the alternate energy sources, biodiesel (BD) is a natural fuel originating from biomasses such as animal fat and vegetable oils and can be used without structural changes of the existing diesel engine $[4,5]$. Furthermore, BD is low-toxic, biodegradable, carbon-neutral fuel, produces less sulphur, $\mathrm{HC}$, and CO, and is an eco-friendly energy source [6, 7].

Global production of BD from vegetable oil is almost completely based on three oil crops: oil palm, soybean, and rapeseed. In Europe, vegetable oil from these three crops makes up over 95\% of BD production [8]. In Brazil, 81\% of BD is produced from soybean oil [9]. Since these raw materials are also used as food, their heavy use to produce biofuel can lead to food shortage and increase in food price $[10,11]$. In addition, the price of BD is higher by $10-50 \%$ compared to the price of conventional diesel (CD), depending on the type of raw oil, making it difficult to commercialize [12]. According to previous studies, the production cost of BD is US\$ 0.34-0.62/L, which is higher than that of CD (excluding taxes), which is US\$ $0.18-0.24 / \mathrm{L}[3,13]$. The price of raw oil is the most important factor of the BD price, accounting for $70-95 \%$ of the total production cost of BD [12, 14]. According to Banković-Ilić et al. [15], the unit price of $\mathrm{BD}$ produced with a raw material of beef tallow was US $\$ 0.27 / \mathrm{L}$, which was lower the unit prices of general BD (US\$ 0.5/L) and of CD (US\$ 0.35/L) by $46 \%$ and $23 \%$, respectively, and for BD produced from soybean oil, its production unit price was up to US\$ $0.7 / \mathrm{L}$ due to the high soybean
This is an Open Access article distributed under the terms of the Creative Commons Attribution Non-Commercial License (http://creativecommons.org/licenses/by-nc/3.0/) which permits unrestricted non-commercial use, distribution, and reproduction in any medium, provided the original work is properly cited.

Copyright (C) 2020 Korean Society of Environmental Engineers
Received August 26, 2019 Accepted December 26, 2019

$\dagger$ Corresponding author

Email: thakim@knu.ac.kr

Tel: +82539505793 Fax: +82539506780

ORCID: 0000-0001-8881-8429 
raw material price (US\$ 0.539/L), which was twice that of CD [13]. To address this problem, many studies have been conducted using non-edible oils, such as waste cooking oils, animal fats, and non-edible vegetable oils, to avoid conflict with food resources. They have reported that economic problems can be solved by cost reduction, environmental benefits can be obtained through the use of waste resources, and that food security problem can be solved by producing BD from non-edible oils [16-19]. Therefore, waste beef tallows are used in the present study as raw materials of $\mathrm{BD}$ to reduce the $\mathrm{BD}$ production cost and obtain the environmental benefits of using waste resources.

According to existing studies, the properties of $\mathrm{BD}$ fuel are greatly affected by the fatty acid composition of the raw oil. When the saturated fatty acid (SFA) content is high, the cetane number and the calorific value increase, but the viscosity and cold-filter plugging point (CFPP) also increase [17, 20-22]. By contrast, if the unsaturated fatty acid (UFA) content is high, the viscosity decreases, but the oxidation safety is degraded [18, 20]. Beef tallow, which is an animal fat, has a high SFA content, of approximately $45 \%$, and soybean oil, a vegetable oil that is most frequently used as raw material of BD, has a high UFA content, of approximately $84 \%$ $[3,20,21,23]$. Therefore, in this study, the optimum conditions for $\mathrm{BD}$ production of raw oils that blend beef tallow and soybean oil are examined, and the fuel properties of the produced BD are analyzed.

Bhuiya et al. [24] reported that the low fuel fluidity of BD due to high kinematic viscosity adversely affects the fuel atomization and can cause problems in the fuel injector. According to Dwivedi et al. [25], the high kinematic viscosity of BD causes problems in engine operation, such as incomplete combustion, carbon deposition, and smoke exhaust. Öner et al. [26] blended an inedible animal tallow BD with $\mathrm{CD}$ and applied it to a direct injection diesel engine; compared to $\mathrm{CD}$, the specific fuel consumption of BD100 increased by up to $15 \%$ and the thermal efficiency decreased by $13 \%$ due to incomplete combustion resulting from poor fuel atomization and low volatility caused by the high kinematic viscosity of BD. Thus, the high kinematic viscosity of BD causes many problems in its use as fuel. Methods to resolve the high viscosity of $\mathrm{BD}$ include blending, heating or pyrolysis, and chemical treatment [27-29]. In a study on the improvement of low-temperature fluidity of $\mathrm{BD}$, Smith et al. found that various additives and chemical modification techniques were effective in improving low-temperature flow characteristics by lowering the crystallization temperature of BD. However, cloud point suppressants such as estolides, triesters, and polyols increased the viscosity of BD. Furthermore, they reported that these chemical-fuel-reforming methods raise the price of $\mathrm{BD}$ and reduce the $\mathrm{BD}$ production yield [30]. Ming et al. added various pour point depressants to palm oil methyl ester and found that when an additive made of a mixture of dihydroxy fatty acid and palm-based polyol at 1:1 was used, the pour point of the palm oil methyl ester decreased from $12^{\circ} \mathrm{C}$ to $5^{\circ} \mathrm{C}$ and the cloud point from $13.5^{\circ} \mathrm{C}$ to $3^{\circ} \mathrm{C}$, thus greatly improving the fluidity of the fuel, though the viscosity increased from $3.49 \mathrm{cP}$ to $5.23 \mathrm{cP}$ [31].

According to Im et al. [32], when BD is ultrasonically irradiated, due to the effect of ultrasonic cavitation, the intricate ring-shaped hydrocarbon compound in the BD is changed to a chain-shaped hydrocarbon compound, and the viscosity is decreased by up to
$27 \%$, and the higher the ratio of $\mathrm{BD}$, the greater the reduction of viscosity. Galle et al. [33] reported that when rapeseed methyl ester is heated to $90^{\circ} \mathrm{C}$, the density and surface tension of $\mathrm{BD}$ are decreased and the kinematic viscosity of BD drops to a level similar to that of CD. According to Yoon et al. [34], in a study on the change of kinematic viscosity according to the temperatures of $\mathrm{BD}$ and $\mathrm{BD}$-diesel compound, the kinematic viscosities of BD100 at $0^{\circ} \mathrm{C}$ and $80^{\circ} \mathrm{C}$ were $39 \mathrm{~mm}^{2} / \mathrm{s}$ and $2.5 \mathrm{~mm}^{2} / \mathrm{s}$, respectively (i.e., the kinematic viscosity decreased by $93.5 \%$ with the temperature rise). In particular, BD100 and BD80 show partial crystallization phenomenon at $0^{\circ} \mathrm{C}$, and kinematic viscosity decreases as the blend ratio of $\mathrm{CD}$ increases.

The kinematic viscosity reduction effect of BD has been reported to be effective in improving engine performance [35, 36]. Du et al. [35] reported that when the kinematic viscosity of BD decreases by $25.5 \%$, the spray droplet size decreases by $41 \%$, which increases the combustion of fuel by $20 \%$. According to Sivalakshmi et al. [36], the decrease in the viscosity of BD by addition of diethyl ether to BD can improve the brake thermal efficiency (BTE) and brake-specific fuel consumption (BSFC).

Labeckas et al. [37] reported that the oxygen content of BD5-BD35 where rapeseed oil $\mathrm{BD}$ and diesel were mixed was $0.9-4.1 \%$, in which the oxygen content of the BD-diesel fuel blends increased as the $\mathrm{BD}$ content increased. The increase in oxygen content according to the increase in the blend ratio of BD has been reported in many previous studies [38-40], and the oxygen contents of soybean oil BD and tallow BD were similar, at $11.81 \%$ and $11.47 \%$, respectively [41]. Accordingly, the oxygen content of the BD-diesel fuel blends is expected to increase as the blend ratio of $\mathrm{BD}$ increases, and the reduction in emission gas is expected through the improvement of combustion quality due to the effect of the increased oxygen content.

In this study, heating and ultrasonic irradiation methods are applied to the blended oil BD, and the kinematic viscosity reduction effects are compared between the two methods to propose a more effective kinematic viscosity reduction method. In addition, blended oil BD with low kinematic viscosity is applied to an agricultural single-cylinder engine, and the engine performance and exhaust emissions are evaluated to examine the viability of blended oil $\mathrm{BD}$ as fuel.

\section{Material and Methods}

\subsection{Materials}

The beef tallow oil used in this experiment was prepared by extracting oil from beef tallow using a microwave oven and removing impurities with a filter. For vegetable oil, soybean oil was used. Table S1shows the blend ratios of the oils used in this experiment. The beef tallow oil and soybean oil were blended at weight ratios of 9:1, 7:3, 5:5, 3:7, and 1:9. The alcohol used in this experiment was 99.8\% methanol (Duksan, Rep. Korea). For catalysts, sodium hydroxide (NaOH; 93\% GR grade, Duksan, Rep. Korea) was used, which is a cheap alkaline catalyst with good reactivity [42]. The acid values (AV) of the blend oils were measured according to KS H ISO 660, and the content of the free fatty acid (FFA) was 
calculated using the measured AV through Eq. (1). Saponification value (SV) was measured using the method specified in $\mathrm{KS} \mathrm{H}$ ISO 3657. The measured results of AV and SV of TASO oil blends are presented in Table S2.

$$
\mathrm{FFA} \%=A V \times \frac{282}{56.1} \times \frac{100}{1000}
$$

\subsection{Transesterification}

The transesterification reaction (TR) experiment used 1 wt $\%$ of $\mathrm{NaOH}$ [43] under the reaction temperature of $60{ }^{\circ} \mathrm{C}$, which below the boiling point of methanol, a stirring speed of $300 \mathrm{rpm}$, and

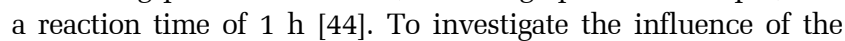
methanol to oil molar ratio on TR, methanol to oil molar ratio was changed to $8: 1,10: 1,12: 1$, and $14: 1$ in consideration of the high FFA content of tallow [45]. After TR, the glycerol layer and $\mathrm{BD}$ were separated using a separating funnel and then washed with distilled water to remove residual impurities. Then, BD was heated at $250^{\circ} \mathrm{C}$ for $60 \mathrm{~min}$ to remove the remaining moisture. TR was repeated five times for each material, and the results were averaged.

\subsection{Analysis of Biodiesel Quality}

The fatty acid methyl ester (FAME) of the produced BD was analyzed in accordance with EN 14103 using a gas chromatograph (GC6850, Agilent, USA) and a flame ionization detector. The BD production yield was calculated using Eq. (2):

$$
\text { BD production yield }(\%)=\frac{\text { Amount of Methyl Ester }[g]}{\text { Amount of oil }[g]} \times 100
$$

The analysis of the physicochemical properties of blended oil BD was requested from Korea Petroleum Quality \& Distribution Authority (K-Petro) according to the quality standards and analysis method in Table S3.

\subsection{Kinematic Viscosity}

The viscosity changes according to heating and ultrasonic irradiation were measured using a heater (PC-420D, Corning, USA), sonicator (VCX750, Sonics \& Materials Inc., USA), and viscometer (LVDV-II+Pro, Brookfield Eng. Laboratory, USA). The temperatures at which the viscosity was measured were $20^{\circ} \mathrm{C}, 40^{\circ} \mathrm{C}, 60^{\circ} \mathrm{C}, 80^{\circ} \mathrm{C}$, $100^{\circ} \mathrm{C}, 120^{\circ} \mathrm{C}$, and $130^{\circ} \mathrm{C}$. To calculate the fuel density after ultrasonic irradiation and heating, the fuel was put in a measuring cylinder and the volume and weight were measured according to temperature. The kinematic viscosity was calculated by dividing absolute viscosity by density, and every experiment was repeated five times. A correlation equation was derived to predict the optimum temperature for each fuel (i.e., at which the kinematic viscosity falls below $2.35 \mathrm{~mm}^{2} / \mathrm{s}$, which is the kinematic viscosity of the CD used in this experiment). The optimum temperature for each fuel was calculated by using the derived Eq. (3), where $v$ is the kinematic viscosity $\left(\mathrm{mm}^{2} / \mathrm{s}\right), \mathrm{T}$ is the temperature $\left({ }^{\circ} \mathrm{C}\right)$, and $\mathrm{a}, \mathrm{b}$, and $\mathrm{c}$ are constants [46]. The fuels used for the viscosity measurements and engine performance tests were TASO BD-diesel fuel blends. The BD ratio was increased by 20 vol.\% for each blend. For example, BD20 contains 20\% BD and 80\% diesel. BD100 means
$100 \%$ BD (without mixing with CD). The used fuels range was BD20-BD100. The optimum temperature for each fuel calculated by the correlation equation was applied to the fuel when it was supplied to the engine.

$$
v=a T^{2}-b T+c
$$

\subsection{Engine Performance}

To compare the output performance and exhaust emissions according to the fuel processing method, heated fuel, ultrasonically irradiated fuel, and fuel with no ultrasonic irradiation (untreated fuel) were supplied to the engine. In the experiments, coolant temperature was $85^{\circ} \mathrm{C}$ and intake air temperature was $25^{\circ} \mathrm{C}$. For the performance test, a full-load test was performed in the engine speed range of 1100-2300 rpm, and the output and exhaust emissions were measured at 300-rpm intervals. The fuel consumption was determined by measuring the consumption time of a certain amount of fuel (300 $\mathrm{mL}$ ) with a stop-watch, and the air flow was measured using an air flow meter (MF-5712, Sirago Ltd., USA). The brake power (BP) was calculated by mounting a torque sensor (YDL-704s, Setech, Rep. Korea) on the engine crankshaft. Eq. (4) is the calculation equation for BP, where $\mathrm{N}$ is the rotation speed (rpm) and $\mathrm{T}$ is the torque $(\mathrm{N} \cdot \mathrm{m})$. After calculating the BP, the BSFC was calculated. To analyze the exhaust gas, an exhaust gas analyzer (HG-550, Airlex, Germany) was installed at $400 \mathrm{~mm}$ from the vent pipe and the exhaust emissions were measured. Table S4 shows the specifications of the power tiller engine used in this experiment (Daedong, ND10DE, Rep. Korea), and its normal rotational speed was 2000 rpm. Fig. S1 shows a schematic diagram of the engine performance tester.

$$
B P(\mathrm{~kW})=\frac{2 \pi N T}{60,000}
$$

\section{Results and Discussion}

\subsection{Properties of Blended-oils Biodiesel}

\subsubsection{Characteristics of biodiesel conversion}

Table 1 shows the FAME content and BD production yield according to the beef tallow ratio and methanol to oil molar ratio of TASO $\mathrm{BD}$. The conditions with good BD production yield were TASO3 and TASO5 for oil blend ratios, and 12:1 for the methanol to oil molar ratio. The optimum conditions for TASO BD production yield were the oil blend ratio of TASO3 and the methanol to oil molar ratio of 12:1. The FAME content and BD production yield were $98.2 \%$ and $82.7 \%$, respectively. In the case of TASO7 and TASO9 (with a high beef tallow content), the FAME content and $\mathrm{BD}$ production yield according to the methanol molar ratio were 88.5-96.3\% and 69.4-78.3\%, respectively. Thus, they did not satisfy the BD criterion of FAME content of $96.5 \%$ or higher. In the case of TR using an alkali catalyst, the reaction occurs actively when the free fatty acid (FFA) content in the raw material oil is $0.5 \%$ or lower $[47,48]$. However, the FFA in the beef tallow is high, at $1-1.3 \%[49,50]$. Thus, it seems that both FAME content and $\mathrm{BD}$ production yield decreased due to a large amount of sap- 
onification during the TR $[51,52]$. This tendency has been found in previous studies. Ma et al. reported that FFA content and moisture content in beef tallow is the crucial factor in TR; as FFA content and moisture content increase, ester yield decreases [47]. Teixeira et al. [53] reported that in alkali-catalyzed transesterification with beef tallow as raw material, a gel-like material was generated in the TR due to the effect of the high SFA of beef tallow. As a result, the ester conversion rate was 91\%. Zhang reported that the ester conversion rate of tallow under the methanol to oil molar ratio of $6: 1$ and the condition of $1 \mathrm{wt} \% \mathrm{NaOH}$ was very low, at $80 \%$ [54]. More methanol is required in the reaction due to the effect of SV and the increased content of FFA as the ratio of tallow increases and $\mathrm{BD}$ generation is inhibited due to the high foamability [55].

Ma et al. [52] found that a high methanol molar ratio increases the reaction speed and conversion rate, and that a raw oil with a high FFA content tends to increase the methanol to oil molar ratio. Furthermore, Encinar et al. [56] reported that the optimum conditions for BD production in the alkali-catalyzed alcoholysis of cynara oil with a high FFA content are a catalyst of 1 wt\% $\mathrm{NaOH}$ and an alcohol molar ratio of 12 mole, and that FAME content is approximately $95 \%$ in these conditions. However, they also reported less methanol than the amount required for TR results in an insufficient, incomplete ester conversion [56]. The high content of saturated fatty acids is difficult to separate from the tallow because they react with soaps and turn into gels [57, 58]. According to some studies, a raw material with a high viscosity and density requires more methanol, but adding an excessive amount of methanol than the optimum conditions lowers the ester conversion

Table 1. Effect of Oils Blend Ratio and Methanol to Oil Molar Ratio on the FAME Content and BD Production Yield

\begin{tabular}{|c|c|c|c|}
\hline $\begin{array}{l}\text { Methanol to } \\
\text { oil molar ratio }\end{array}$ & $\begin{array}{l}\text { Blend } \\
\text { ratio }\end{array}$ & $\begin{array}{c}\text { FAME content } \\
\text { (\%) }\end{array}$ & $\begin{array}{c}\text { BD production yield } \\
\text { (\%) }\end{array}$ \\
\hline \multirow{5}{*}{$14: 1$} & TASO9 & 94.8 & 76.1 \\
\hline & TASO7 & 95.5 & 78.2 \\
\hline & TASO5 & 94.0 & 76.5 \\
\hline & TASO3 & 93.2 & 74.9 \\
\hline & TASO1 & 89.4 & 70.2 \\
\hline \multirow{5}{*}{$12: 1$} & TASO9 & 94.2 & 75.7 \\
\hline & TASO7 & 96.3 & 78.3 \\
\hline & TASO5 & 97.8 & 81.1 \\
\hline & TASO3 & 98.2 & 82.7 \\
\hline & TASO1 & 93.1 & 74.2 \\
\hline \multirow{5}{*}{ 10:1 } & TASO9 & 92.6 & 73.2 \\
\hline & TASO7 & 94.4 & 77.7 \\
\hline & TASO5 & 96.8 & 80.3 \\
\hline & TASO3 & 97.4 & 81.7 \\
\hline & TASO1 & 96.7 & 79.8 \\
\hline \multirow{5}{*}{$8: 1$} & TASO9 & 88.5 & 69.4 \\
\hline & TASO7 & 93.8 & 75.5 \\
\hline & TASO5 & 95.6 & 73.9 \\
\hline & TASO3 & 96.5 & 74.9 \\
\hline & TASO1 & 97.1 & 80.7 \\
\hline
\end{tabular}

rate because the increased solubility interferes with the separation of glycerin and ester [43, 57]. Ding et al. reported that high FFA content and moisture content in raw material oils reduce the consumption and catalytic effect of the catalyst, and the higher the FFA content, the greater amount of methanol required [59].

The results of this study determined the optimum methanol molar ratio, which is higher than the methanol to oil molar ratio used for alkaline TR of vegetable oils [45]. This is due to the high FFA content in beef tallow, the high moisture content in raw material oils, and the high concentration of SFA.

\subsubsection{Fuel properties of blended-oils biodiesel}

Table S5 shows the composition of FAME in TASO3 BD, soybean $\mathrm{BD}$ (SO BD) [9], and tallow BD (TA BD) [17]. The contents of SFA and UFA in TASO3 BD were $25.3 \%$ and $72.3 \%$, respectively. The SFA content increased and the UFA content decreased compared to SO BD. However, compared to TA BD, the SFA content decreased and the UFA content increased. This composition of FAME has significant effects on the fuel properties such as cetane number, calorific value, and kinematic viscosity [58, 60].

Table S6 shows the fuel properties of TASO3 BD, CD, SO BD [3, 9, 21, 22, 31, 51, 61, 62], and TA BD [3, 22, 26, 61-65]. Among the fuel properties, cetane number is closely related to combustion qualities, such as combustion delay and diffusion combustion. When the cetane number is high, the combustion quality improves and the toxic gas emission reduces [20,66]. The cetane number of TASO3 BD increased because it has high contents of SFAs such as palmitic (C16:0) and stearic (C18:0) acids, and lower contents of UFAs such as linoleic (C18:2) and linolenic (C18:3) acids, compared to those of SO BD [66].

The calorific value of TASO3 BD decreased to $39.7 \mathrm{MJ} / \mathrm{kg}$ compared to that of TA BD, which appears to be due to the reduction of SFAs with a large molecular weight. Furthermore, the calorific value of $\mathrm{BD}$ is generally lower than that of $\mathrm{CD}$ due to the oxygen content, which is $10-12 \%$ [20]. Verduzco et al. [67] reported that the calorific value of $\mathrm{BD}$ is affected by the molecular weight of fatty acid, and the calorific values of SFAs such as stearic (C18:0) acids are higher than those of UFAs such as oleic acid (C18:1) and linoleic acid (C18:2).

CFPP is an indicator of fuel fluidity at low temperatures. CFPP causes problems such as the clogging of fuel line and fuel filter due to fuel crystallization at low temperatures [53, 64]. The CFPP of TASO3 $\mathrm{BD}$ is $-2.5^{\circ} \mathrm{C}$, which is superior compared to the $8-10^{\circ} \mathrm{C}$ of $\mathrm{TAB} \mathrm{BD}$, and satisfies BD quality standard of CFPP lower than $0^{\circ} \mathrm{C}$. However, it is expected that the problems of CFPP can be solved if the kinematic viscosity of $\mathrm{BD}$ is reduced, because doing so can improve the low-temperature flow characteristics [3, 30, 67].

The high kinematic viscosity of $\mathrm{BD}$ is due to the SAF content and the number of carbon atoms. The kinematic viscosity of TASO3 BD satisfies the BD quality standard of $1.9-5.0 \mathrm{~mm}^{2} / \mathrm{s}$. Furthermore, the kinematic viscosity of TASO3 BD is lower than that of TA $\mathrm{BD}$ due to the lower SFA content [15, 58, 68]. However, the kinematic viscosity of TASO3 is approximately 1.9 times higher than that of CD and can lower the combustion quality, increase fuel consumption ratio, and cause carbon deposits and oil dilution [15, 57, 62, 69]. 
The residual carbon and sulfur contents of TASO3 BD are much lower than those of CD. Thus, it is expected that when TASO3 $\mathrm{BD}$ is applied to the engine, toxic gas emissions will be low. According to existing studies, the contents of carbon monoxide, unburned hydrocarbons, and particulate matter (PM) in BD are lower than those of $\mathrm{CD}$, because BD has low sulfur and aromatic contents [4, 70].

An analysis of the fuel properties of TASO3 BD confirmed that it satisfies the $\mathrm{BD}$ quality standards owing to the harmonious combination of SFA and UFA compositions.

\subsection{Kinematic Viscosity Changes}

Fig. 1(a) shows the changes in kinematic viscosity when TASO3 BDs (BD20-BD100) blended with diesel were heated. The red straight line in this graph indicates the kinematic viscosity of $\mathrm{CD}$. The graph also shows the correlation equations of temperature and kinematic viscosity by $\mathrm{BD}$ ratio.

The optimum heating temperature for each fuel where the kinematic viscosity falls below $2.35 \mathrm{~mm}^{2} / \mathrm{s}$, which is the kinematic viscosity of $\mathrm{CD}$, was calculated by using the correlation equation for each TASO3 BD-diesel fuel blend ratio. The lowest kinematic viscosity was $2.92 \mathrm{~mm}^{2} / \mathrm{s}$ at $124^{\circ} \mathrm{C}$ for $\mathrm{BD} 100$, and $2.53 \mathrm{~mm}^{2} / \mathrm{s}$ at $111^{\circ} \mathrm{C}$ for $\mathrm{BD} 80$. Thus, the kinematic viscosity did not fall below that of $\mathrm{CD}$ by heating. However, the kinematic viscosity values of $\mathrm{BD} 60, \mathrm{BD} 40$, and $\mathrm{BD} 20$ fell below $2.35 \mathrm{~mm}^{2} / \mathrm{s}$ at $93^{\circ} \mathrm{C}$, $86^{\circ} \mathrm{C}$, and $60.5^{\circ} \mathrm{C}$, respectively. Furthermore, the higher the blend ratio of $\mathrm{BD}$, the higher the kinematic viscosity became, and the higher the $\mathrm{BD}$ ratio, the greater the reduction of kinematic viscosity became [71]. The change in the kinematic viscosity of BD by temperature is much affected by the fatty acid composition. According to Yuan et al. [72], when stearic acid, which is the fatty acid with the highest kinematic viscosity, is heated to $98.9^{\circ} \mathrm{C}$, the kinematic viscosity decreased from $5.61 \mathrm{~mm}^{2} / \mathrm{s}$ to $2 \mathrm{~mm}^{2} / \mathrm{s}$, showing the largest reduction of kinematic viscosity. Furthermore, when soybean methyl ester and yellow grease methyl ester, with kinematic viscosity of $5.7 \mathrm{~mm}^{2} / \mathrm{s}$ and $7.1 \mathrm{~mm}^{2} / \mathrm{s}$ at $20^{\circ} \mathrm{C}$, respectively, were heated to $100^{\circ} \mathrm{C}$, the kinematic viscosities decreased to 1.38 $\mathrm{mm}^{2} / \mathrm{s}$ and $1.51 \mathrm{~mm}^{2} / \mathrm{s}$, respectively, similar to the results of the present study.
Fig. 1(b) shows the changes in kinematic viscosity of the ultrasonically irradiated TASO3 BD-diesel fuel blends. The equations in the graph are correlation equations between the fuel temperature and kinematic viscosity according to ultrasonic irradiation. These were used to calculate the temperature at which the kinematic viscosity falls below that of $\mathrm{CD}$. The kinematic viscosity was $3.05 \mathrm{~mm}^{2} / \mathrm{s}$ at $107^{\circ} \mathrm{C}$ for BD100, $2.85 \mathrm{~mm}^{2} / \mathrm{s}$ at $108^{\circ} \mathrm{C}$ for BD80, and $2.65 \mathrm{~mm}^{2} / \mathrm{s}$ at $100^{\circ} \mathrm{C}$ for BD60. The kinematic viscosity of the BDs did not decrease below $2.35 \mathrm{~mm}^{2} / \mathrm{s}$, which is the kinematic viscosity of $\mathrm{CD}$. The kinematic viscosity values of $\mathrm{BD} 40$ and $\mathrm{BD} 20$ dropped below $2.35 \mathrm{~mm}^{2} / \mathrm{s}$ at $79^{\circ} \mathrm{C}$ and $67.5^{\circ} \mathrm{C}$, respectively. According to Manh et al. [73], when the BD temperature changed from 10 to $60^{\circ} \mathrm{C}$ through ultrasonic irradiation, the kinematic viscosity of tung-oil $\mathrm{BD}$ decreased by approximately $41 \%$, from $13.44 \mathrm{~mm}^{2} / \mathrm{s}$ to $7.21 \mathrm{~mm}^{2} / \mathrm{s}$. Thus, the tendency of kinematic viscosity reduction through ultrasonic irradiation was similar to this trend.

The results of experiment on the kinematic viscosity changes of the TASO3 BD-diesel fuel blends showed that the kinematic viscosity reduction effects of heating and ultrasonic irradiation were similar. However, heating is a more effective kinematic viscosity reduction method because it takes less time than the ultrasonic irradiation and the equipment is cheaper and simpler compared to the ultrasonic irradiation method.

\subsection{Engine Performance}

\subsubsection{Brake power}

Fig. 2 shows the BP at $1400-2300 \mathrm{rpm}$ of the TASO3 BD-diesel fuel blends according to the fuel treatment method. The striped bar indicates the BP from CD. For BD20, which was a commercial $\mathrm{BD}$ blend ratio, the BPs of untreated fuel, heated fuel, and ultrasonically irradiated fuel were 93.7-96.5\%, 97.4-98.8\%, and 97.1-98.6\% compared to that of diesel at the 1400-2300 rpm, and the mean BPs of untreated BD20, heated BD20, and ultrasonically irradiated BD20 were $6.99 \mathrm{~kW}, 7.17 \mathrm{~kW}$, and $7.14 \mathrm{~kW}$, respectively, which were reduced by $4.4 \%, 1.9 \%$, and $2.3 \%$, respectively, compared to that of $\mathrm{CD}(7.31 \mathrm{~kW})$. The higher the ratio of $\mathrm{BD}$, the lower the $\mathrm{BP}$ relative to $\mathrm{CD}$ was. This seems to be due to the low calorific value due to the effect of the oxygenation of $\mathrm{BD}[74,75]$. In addition,
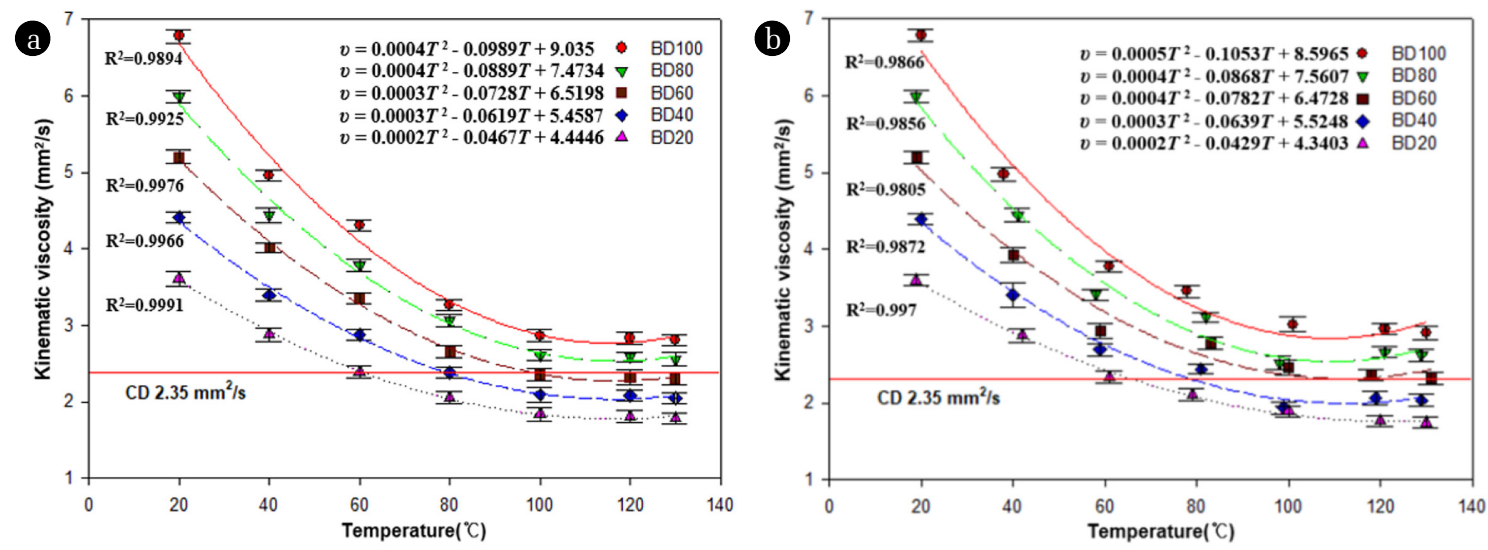

Fig. 1. Kinematic viscosity changes of heated and ultrasonically irradiated TASO3 BD-diesel fuel blends. (a) Heating, (b) Ultrasonic. 

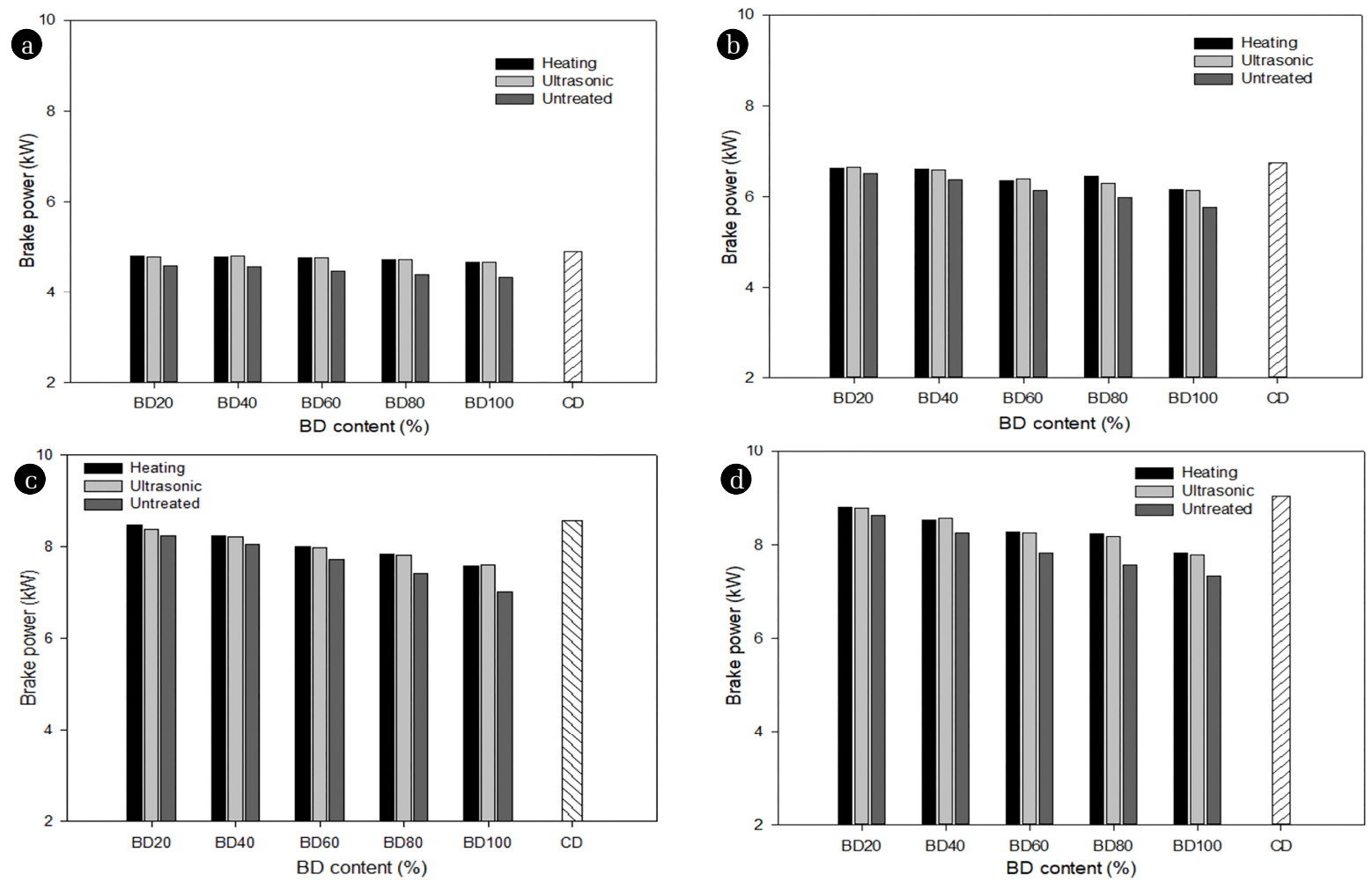

Fig. 2. Brake power of TASO3 BD-diesel fuel blends according to fuel treatment method. (a) At $1400 \mathrm{rpm}$ (b) At $1700 \mathrm{rpm}$ (c) At $2000 \mathrm{rpm}$ (d) At $2300 \mathrm{rpm}$.

the high kinematic viscosity of BD negatively affects the combustion quality [76, 77]. Utlu et al. [77] reported that the torque and power of WFOME were lower than those of CD due to the effects of high kinematic viscosity and density, and lower calorific values, by $4.3 \%$ and $4.5 \%$, respectively.

The BPs of untreated fuel, heated fuel, and ultrasonically irradiated fuel at the $2000 \mathrm{rpm}$ were $81.8-96.2 \%, 88.6-98.8 \%$, and 88.8-97.9\% relative to the BP of CD, respectively. Depending on the fuel treatment method, the BPs of heated or ultrasonically irradiated fuel were higher than that of the untreated fuel. The cause of this is considered to be the improved combustion quality through the atomization of spray droplets due to the reduced kinematic viscosity of fuel [78].

\subsubsection{Brake-specific fuel consumption}

Fig. 3 shows the BSFC at $1400-2300 \mathrm{rpm}$ according to the treatment method of TASO3 BD-diesel fuel blends. For BD20, the BSFCs of untreated fuel, heated fuel, and ultrasonically irradiated fuel were increased by $3.7-8.3 \%, 1.7-3.5 \%$, and $1.5-4.1 \%$ compared to the BSFC of diesel, respectively, at $1400-2300 \mathrm{rpm}$, and the average BSFCs of untreated BD20, heated BD20, and ultrasonically irradiated BD20 were $295.1 \mathrm{~g} / \mathrm{kWh}, 283.3 \mathrm{~g} / \mathrm{kWh}$, and $285 \mathrm{~g} / \mathrm{kWh}$, respectively, which were higher than that of CD by $6.6 \%, 2.3 \%$, and $2.9 \%$, respectively. The higher $\mathrm{BD}$ blend ratio was, the higher the BSFC became. This seems to be due to the low calorific value of BD [79, 80]. The BSFCs of heated fuel and ultrasonically irradiated fuel were lower than that of the untreated fuel. In particular, the BSFC of untreated fuel was higher by up to $11 \%$ and up to $26 \%$ than those of heated fuel and CD, respectively. The high kinematic viscosity of untreated fuel increases the spray particle size and causes combustion delay, resulting in incomplete combustion [81, 82]. Some studies found that the BSFC was increased by the changed ignition time due to the high cetane number of BD [83]. The BSFC of the heated fuel BD20 increased by approximately $0.02 \%$ relative to $\mathrm{CD}$ and was similar to the level of $\mathrm{CD}$. This is the result of complete combustion due to the decreased kinematic viscosity [80].

As described in the above results, the average BP at $1400-2300$ rpm of TASO3 BD20 heated at $60.5^{\circ} \mathrm{C}$ was $1.17 \mathrm{~kW}$, which was lower than that of CD by $1.9 \%$, and the BSFC was $283.3 \mathrm{~g} / \mathrm{kWh}$, which was higher than that of CD by $2.3 \%$. The average BP and BSFC of the heated BD100 were lower than that of CD by $6.9 \%$, and higher by $10.9 \%$. However, the calorific value of TASO3 BD was $39.7 \mathrm{MJ} / \mathrm{kg}$, which was lower than that of CD (45 MJ/kg) by $11.7 \%$, indicating that the loss of calorific value of diesel was larger than that of $\mathrm{BD}[84,85]$.

The kinematic viscosity of BD significantly affected the combustion quality parameters, such as fuel's Sauter mean diameter (SMD), injected fuel amount, injection timing, and injection pattern [86-88]. Because the high viscosity of $\mathrm{BD}$ increases friction with the nozzle surface during fuel injection, the injection velocity of BD becomes slower than that of fuel injection of CD, making fuel spray travel shorter [87]. In addition, the increase in spray droplets due to the high surface tension and viscosity of BD causes incomplete 

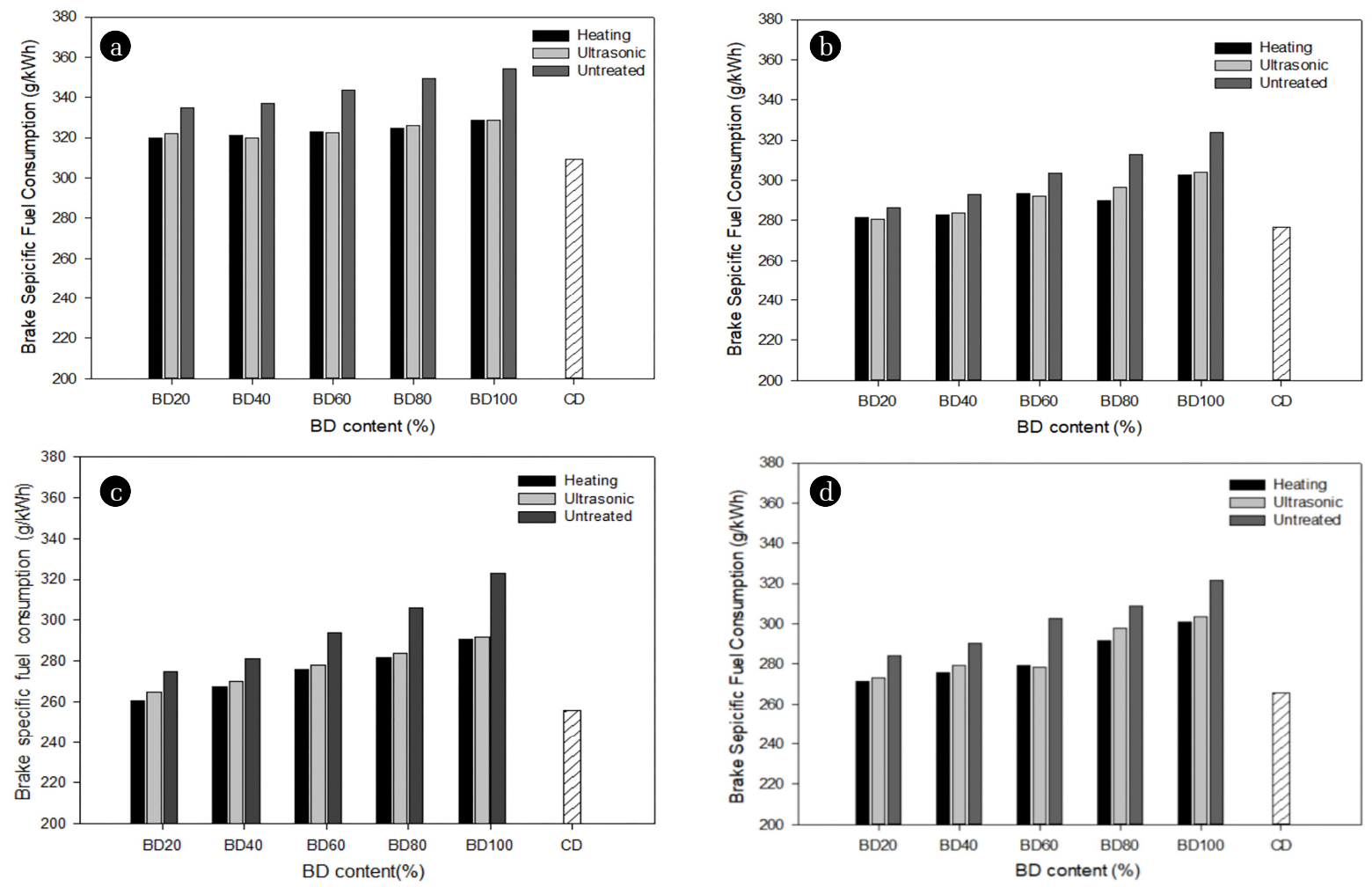

Fig. 3. Brake-specific fuel consumption of TASO3 BD-diesel fuel blends according to fuel treatment method. (a) At $1400 \mathrm{rpm}$ (b) At $1700 \mathrm{rpm}$ (c) At $2000 \mathrm{rpm}$ (d) At $2300 \mathrm{rpm}$.

combustion eventually [87], thereby creating power losses, resulting in the reduction in combustion efficiency parameters such as brake thermal efficiency [77, 89]. A study by Selim reported that the reduction in viscosity of $\mathrm{BD}$ facilitated the mix of air and fuel and increased combustion temperature, thereby shortening the ignition delay. Furthermore, it reported that higher heat release rate than that of CD could be obtained through fuel spray through viscosity reduction and improvement of processes that mixed air and fuel [90]. A study also found that the peak combustion pressure was increased as the blend ratio of $\mathrm{BD}$ was higher due to the improvement of combustion quality as a result of ignition delay being shortened due to the oxygenated characteristics of $\mathrm{BD}$ and high cetane number [87]. Accordingly, the combustion quality improved by the reduction in kinematic viscosity may also improve the engine performance such as BSFC and BP. Thus, BD20 is used, which is the commercial BD ratio, as it is considered most efficient for the engine power and BSFC to heat TASO3 BD20 to $60.5^{\circ} \mathrm{C}$.

\subsubsection{Exhaust emissions}

Fig. 4 shows the exhaust emissions according to the fuel treatment method of TASO3 BD-diesel fuel blends at various engine speeds ranging from 1400-2300 rpm. The striped bar indicates the emissions from CD. The CO emissions of the heated fuel and ultrasonically irradiated fuel were decreased more than in $\mathrm{CD}$ in all engine speeds. CO is generated due to insufficient combustion of fuel and partial oxidation of carbon atoms, and CO emission was reduced as the engine speed increased [91]. At the low engine speed, fuel/air equivalence ratio and combustion gas temperature were low, entailing increased CO emissions due to the incomplete combustion [91]. As the engine speed increased, a fuel/air equivalence ratio and combustion gas temperature increased, resulting in the reduction in $\mathrm{CO}$ emissions due to the facilitated conversion of CO into $\mathrm{CO}_{2}$ [92]. In addition, the ignition delay was shortened by the BD's high oxygen content, and CO emissions were reduced as the combustion efficiency was increased [92]. As shown in Fig. 4(c), The CO emissions of heated fuel and ultrasonically irradiated fuel decreased by up to $13.2 \%$ and $11.8 \%$ relative to $\mathrm{CD}$, respectively. This is considered to be the result of complete combustion due to the reduced kinematic viscosity of fuel [93]. Furthermore, the CO emissions decreased as the ignitability improved by the high cetane number of $\mathrm{BD}$, and the $\mathrm{BD}$ blend ratio increased due to the oxygenation property of BD [94]. The CO emissions of the untreated fuel increased relative to $\mathrm{CD}$ as a result of incomplete combustion due to the high kinematic viscosity.

Fig. 5 shows the HC emissions according to the fuel treatment method of TASO3 BD-diesel fuel blends at various engine speeds ranging from 1400-2300 rpm. HC was a compound of incompletely combusted carbon and hydrogen molecules, and it was generated due to the effects of various causes such as low combustion temperature and ignition delay [95, 96]. Accordingly, HC emissions were lowest at the normal rotational speed of $2000 \mathrm{rpm}$, at which BSFC was the lowest. The HC emissions of heated fuel at $2000 \mathrm{rpm}$, ultrasonically irradiated fuel, and untreated fuel decreased by up 

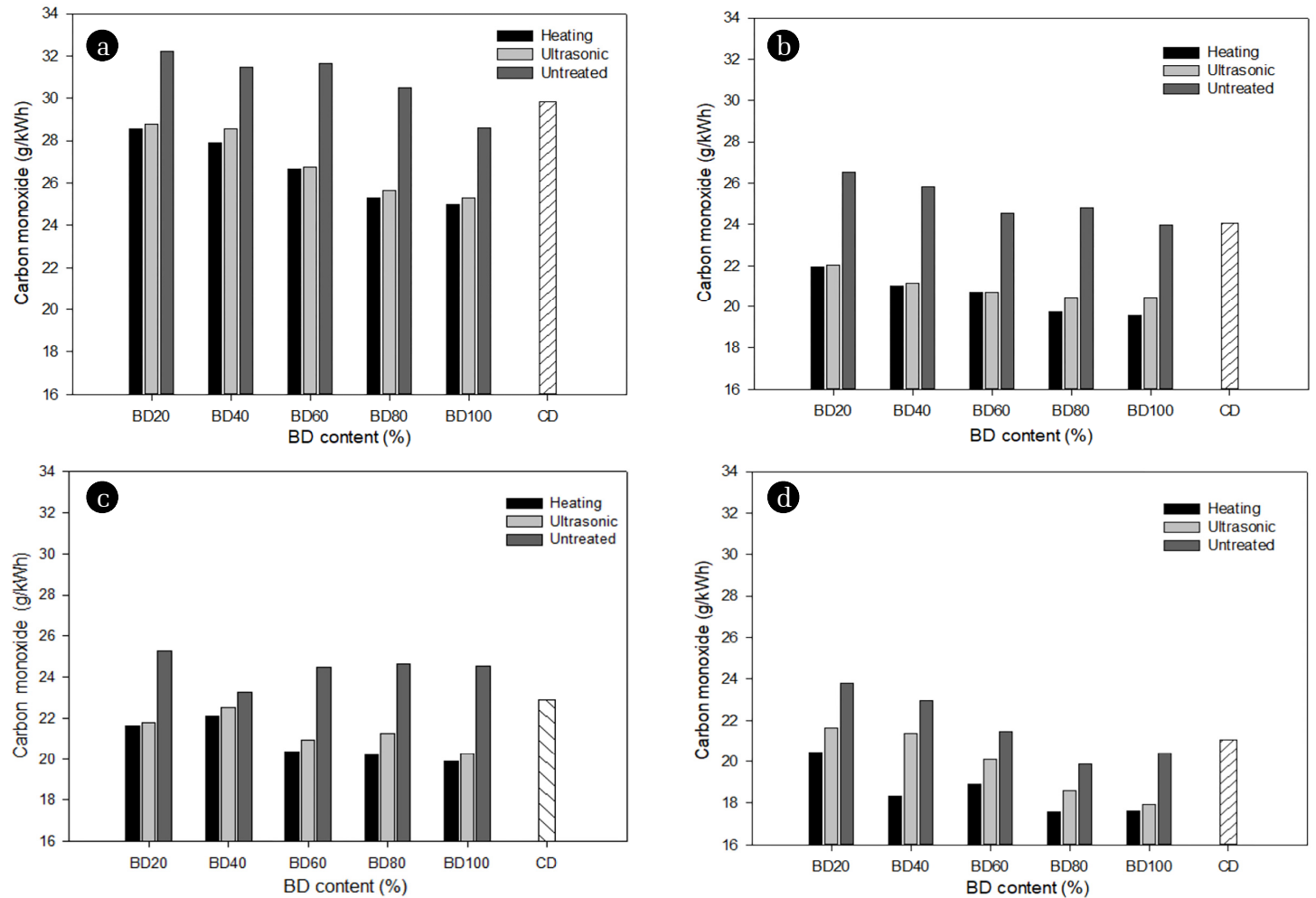

Fig. 4. Comparison of $\mathrm{CO}$ emission from untreated, heated, and ultrasonically irradiated TASO3 BD-diesel fuel blends. (a) At 1400 rpm (b) At $1700 \mathrm{rpm}$ (c) At $2000 \mathrm{rp}$ (d) At $2300 \mathrm{rpm}$.
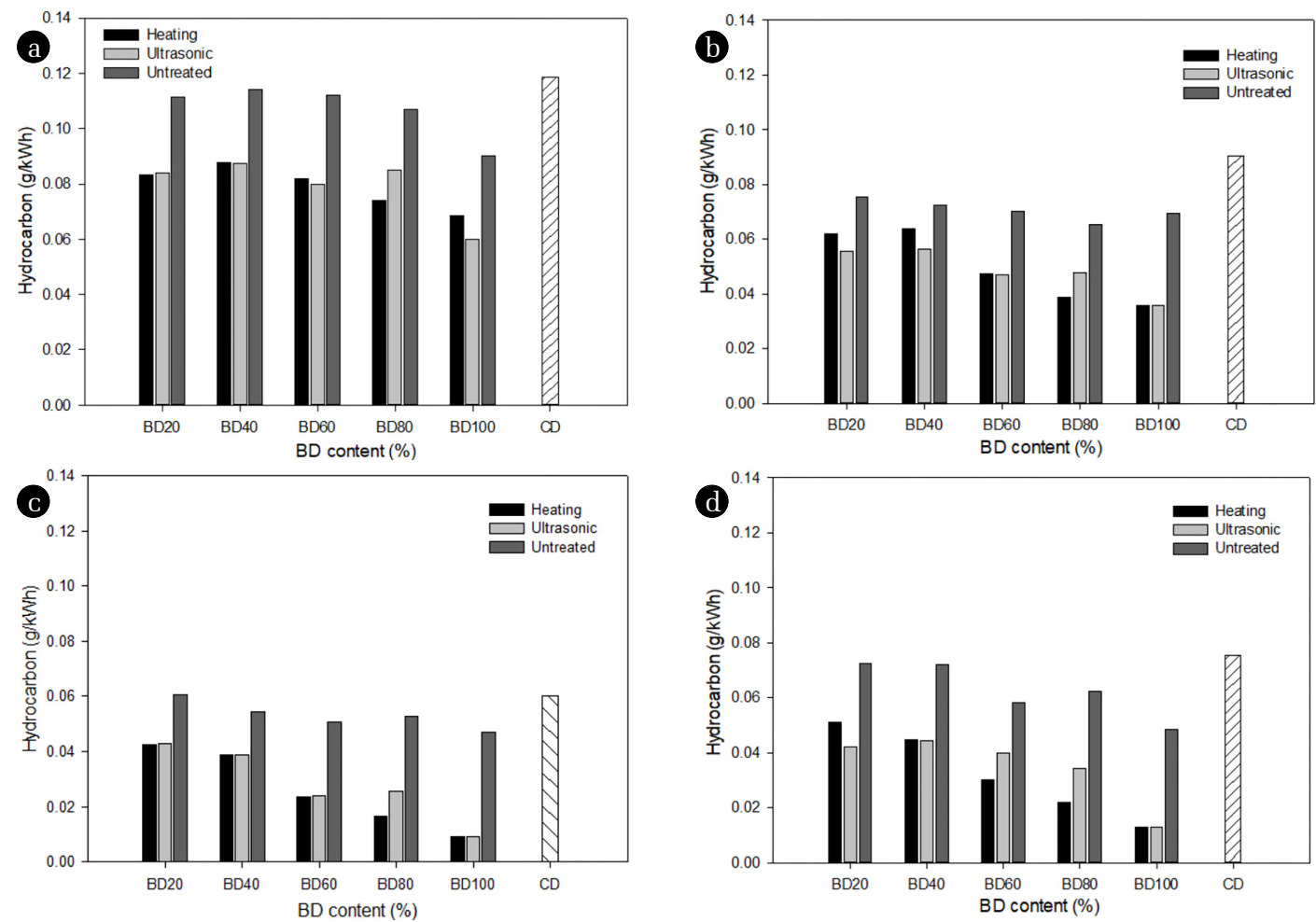

Fig. 5. Comparison of $\mathrm{HC}$ emissions from untreated, heated, and ultrasonically irradiated TASO3 BD-diesel fuel blends. (a) At 1400 rpm (b) At $1700 \mathrm{rpm}$ (c) At $2000 \mathrm{rpm}$ (d) At $2300 \mathrm{rpm}$. 

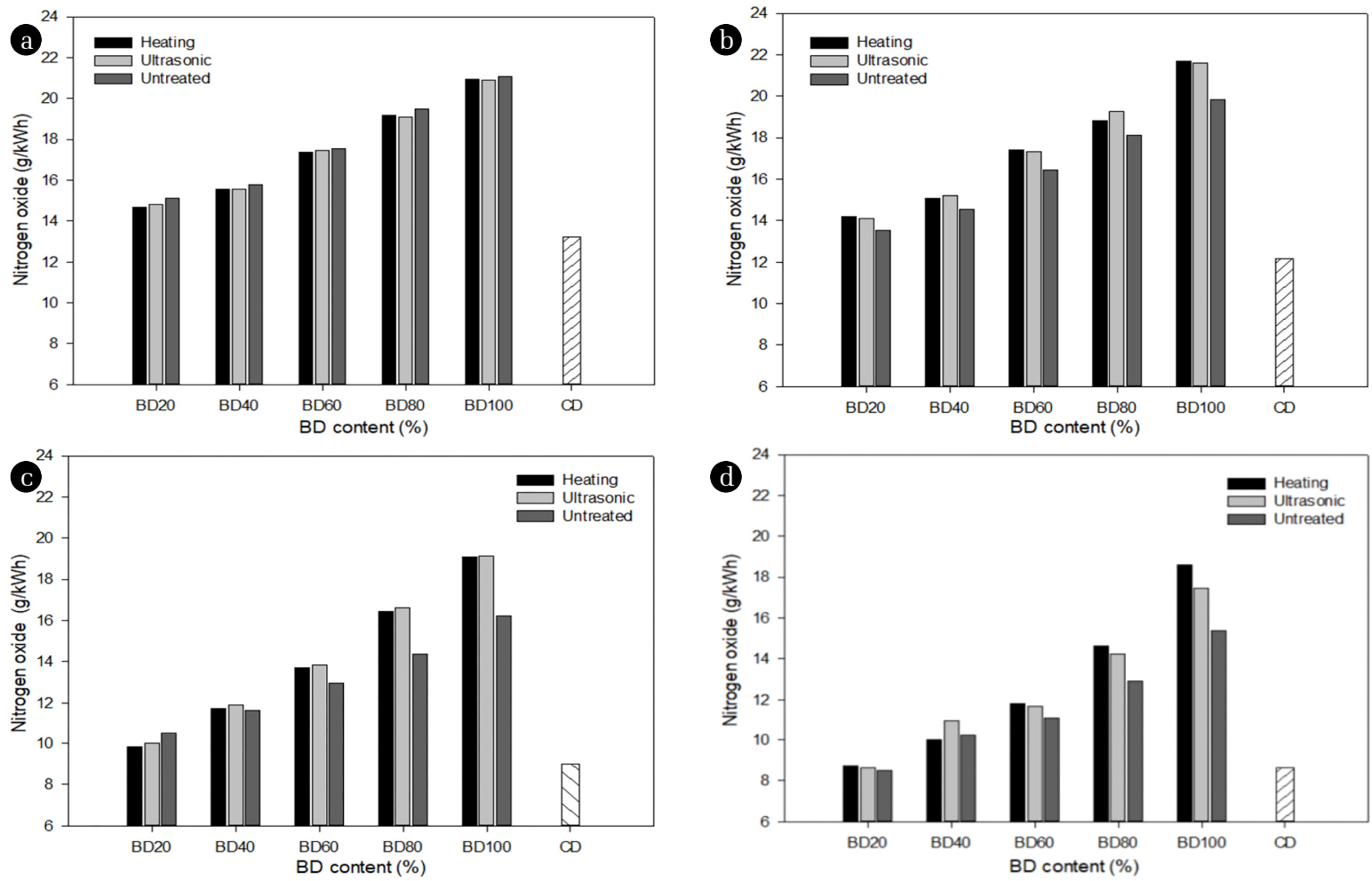

Fig. 6. Comparison of $\mathrm{NO}_{\mathrm{x}}$ emissions from untreated, heated, and ultrasonically irradiated TASO3 BD-diesel fuel blends. (a) At 1400 rpm (b) At $1700 \mathrm{rpm}$ (c) At $2000 \mathrm{rpm}$ (d) At $2300 \mathrm{rpm}$.

to $84.6 \%, 84.7 \%$, and $21.6 \%$ relative to $\mathrm{CD}$, respectively. The HC emissions of untreated fuel were higher than those of heated fuel and ultrasonically irradiated fuel because of the ignition delay due to the increased spray particle size caused by the high kinematic viscosity of untreated fuel [93]. In addition, HC emission was reduced according to the increased BD blend ratio of the fuel. The reduction of $\mathrm{HC}$ emissions according to the increased BD blend ratio of the fuel is considered an effect of the low carbon content of $\mathrm{BD}$ [97] and oxygenated characteristic of BD, which was advantageous in unburned HC oxidation [98]. In addition, it has been reported that $\mathrm{HC}$ emission was reduced by the high cetane number of SFA, so high SFA of beef tallow could be effective in the reduction in $\mathrm{HC}$ emission [99].

Fig. 6 shows the $\mathrm{NO}_{\mathrm{x}}$ emissions according to the fuel treatment method of TASO3 BD-diesel fuel blends at various engine speeds ranging from $1400-2300 \mathrm{rpm}$. The $\mathrm{NO}_{\mathrm{x}}$ emissions decreased with increase in engine speed, which is primarily due to the shorter residence time available for $\mathrm{NO}_{\mathrm{x}}$ formation, because of the increase in volumetric efficiency and velocity of flow of the reactant mixture at higher engine speeds [100].

As shown in Fig. 6(c), the $\mathrm{NO}_{\mathrm{x}}$ emissions of untreated fuel, heated fuel, and ultrasonically irradiated fuel increased by up to $110 \%$ relative to diesel. Furthermore, the $\mathrm{NO}_{\mathrm{x}}$ emissions of untreated fuel were higher than those of heated fuel and ultrasonically irradiated fuel. This is considered to be caused by atomization of droplets due to reduced kinematic viscosity and the generation of high combustion heat due to from the oxygenation of BD [101, 102]. In addition, a shorter ignition delay could allow the fuel mixture and initial combustion products to have a longer residence time at elevated temperature, thereby increasing thermal $\mathrm{NO}_{\mathrm{x}}$ formation [103].

The $\mathrm{NO}_{\mathrm{x}}$ emissions of heated fuel and ultrasonically irradiated fuel of BD20, which is a commercial BD ratio, at $2000 \mathrm{rpm}$ were increased by $9 \%$ and $10.8 \%$, respectively, compared to that of CD. Thus, a way to reduce $\mathrm{NO}_{\mathrm{x}}$ is required. According to existing study results, low-temperature combustion (LTC) increased the ignition delay, thereby shortening the diffused combustion range, resulting in the effect of decrease in generating $\mathrm{NO}_{\mathrm{x}}$ [104]. One of the LTC methods is a method using exhaust gas recirculation, which was widely used to reduce $\mathrm{NO}_{\mathrm{x}}$, and a study reported that it had a $\mathrm{NO}_{\mathrm{x}}$ reduction effect by up to $50 \%$ [103]. In addition, the increased $\mathrm{NO}_{\mathrm{x}}$ can be reduced by $6-10 \%$ through the methods of SCR (selective catalytic reduction) and NAC ( $\mathrm{NO}_{\mathrm{x}}$ absorber catalyst), which are after-treatment approach [105]. Since the power tiller engine used in the study was not restricted by the environmental regulation standards of exhaust gases, the technology to reduce exhaust gases was not applied. Accordingly, if the aforementioned technology to reduce $\mathrm{NO}_{\mathrm{x}}$ is used, it is expected to reduce the increasing $\mathrm{NO}_{\mathrm{x}}$ emission during the use of BD.

Fig. 7 shows the $\mathrm{CO}_{2}$ emissions according to the fuel treatment method of TASO3 BD-diesel fuel blends at various engine speeds ranging from $1400-2300 \mathrm{rpm}$. The $\mathrm{CO}_{2}$ emission was reduced as the engine speed increased. In the full load test of $100 \%$ open throttle, more $\mathrm{CO}_{2}$ was emitted at a lower engine speed due to the rich fuel-blend combustion inside the cylinder [76]. A study by Al-Widyan et al. [106] reported that $\mathrm{CO}_{2}$ emissions increased 

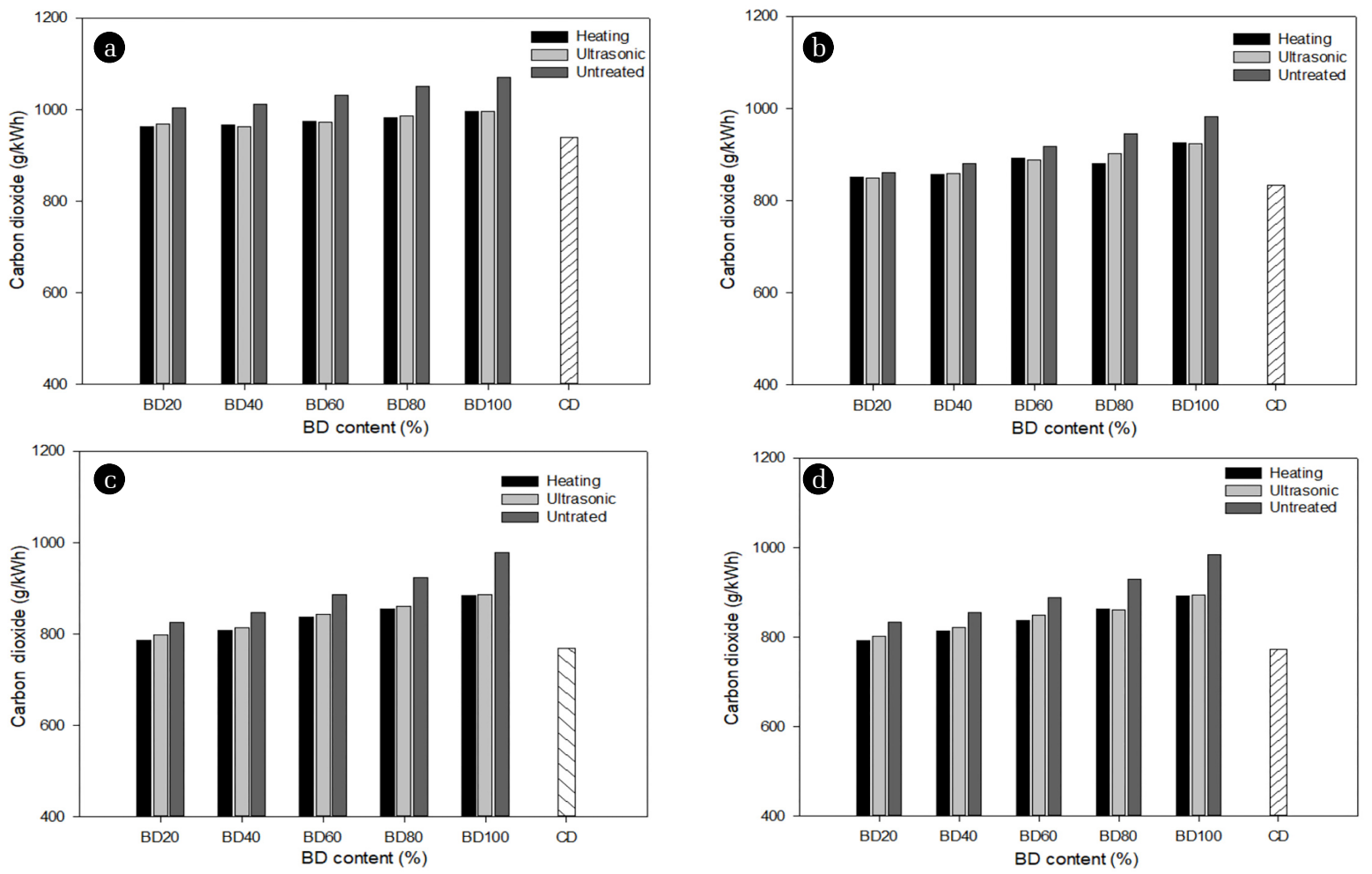

Fig. 7. Comparison of $\mathrm{CO}_{2}$ emissions from untreated, heated, and ultrasonically irradiated TASO3 BD-diesel fuel blends. (a) At 1400 rpm (b) At $1700 \mathrm{rpm}$ (c) At $2000 \mathrm{rpm}$ (d) At $2300 \mathrm{rpm}$.

at a lower rotational speed because a fuel/air equivalence ratio became rich due to the fixed fuel rack position in a full load engine test result of $\mathrm{BD}$ produced from wasted vegetable oil. At 2000 rpm, the $\mathrm{CO}_{2}$ emission trend according to the fuel treatment method showed that the $\mathrm{CO}_{2}$ emissions of heated fuel, ultrasonically irradiated fuel, and untreated fuel increased by up to 15\%, 15.3\%, 27.1\% relative to $\mathrm{CD}$, respectively. Furthermore, the higher the BD ratio was, the larger the $\mathrm{CO}_{2}$ emissions became. This is considered to be caused by the increase of BSFC due to the increased BD ratio and the increase of oxygen content [94, 107]. However, a study found that since $\mathrm{BD}$ is a carbon-neutral fuel, the $\mathrm{CO}_{2}$ emissions decreased by $50-80 \%$ relative to $\mathrm{CD}$ by natural circulation [108]. Therefore, it is considered that the increase of $\mathrm{CO}_{2}$ emissions by the use of BD is not a problem.

Although this study did not measure PM emissions, a previous study reported that the PM emission emitted when using BD was reduced by up to $91 \%$ compared to that of $\mathrm{CD}$, and PM emissions were decreased further as the BD blend ratio increased [84]. The reduction in PM was due to the complete combustion as a result of high oxygen content in $\mathrm{BD}$ and oxidation promotion of soot, and the lack of aromatic and sulphur compounds in the $\mathrm{BD}$ also further contributed [109, 110]. PM formation is the reason of the development of elemental carbon soot and condensation of hydrocarbons [106]. Since emitted HC is absorbed in the surface of PMs, thereby increasing the soluble organic fraction, which is a main ingredient of the PMs [110], PM emissions increase as the HC emissions increase [111]. In this study, the HC emissions were decreased by up to $84.6 \%$ compared to those of $\mathrm{CD}$, and that of
BD20 was dropped by up to $26-41 \%$ compared to that of CD. Thus, since the reduced HC emissions would affect the PM emissions, the reduction of PM emissions is also predicted. However, in some research, the PM emissions was nearly the same as those of $\mathrm{CD}$ or slightly increased as the combustion quality worsened due to worse fuel atomization as a result of high viscosity of BD [82]. The high kinematic viscosity of BD inhibited the fuel atomization thereby increasing the fuel's surface area, entailing the increase in PM emissions [112, 113]. In this regard, the atomization of spray droplet due to the reduction treatment of kinematic viscosity of $\mathrm{BD}$ would be effective in the reduction in PM emissions along with the improvements of combustion quality.

Heating and ultrasonic irradiation, which are methods to reduce the kinematic viscosity of $\mathrm{BD}$, are both effective in reducing the $\mathrm{HC}$ and $\mathrm{CO}$ emissions. However, a technology to reduce $\mathrm{NO}_{\mathrm{x}}$ is required for the reduction of increased $\mathrm{NO}_{\mathrm{x}}$. Heated fuel and ultrasonically irradiated fuel showed similar emission performances. However, the heating system is simpler and more economical than the ultrasonic system.

\section{Conclusions}

The optimum conditions for the production of beef tallow and soybean blended oil BD were examined. The TASO3 and methanol to oil molar ratio of 12:1 showed an excellent conversion ratio, with a FAME content of $98.2 \%$ and a BD production yield of $82.7 \%$. Furthermore, the analysis result of the fuel properties of TASO3 
BD satisfied the BD quality standards. Thus, the viability of BD blended with waste tallow as fuel was verified.

To solve the high kinematic viscosity problem of $\mathrm{BD}$, the optimum temperature of each fuel was investigated through BD kinematic viscosity reduction experiments using heating and ultrasonic irradiation. When the engine performance and exhaust emissions were evaluated by applying the optimum temperature, the BP and BSFC of the heated fuel were higher than those of ultrasonically irradiated fuel and untreated fuel. However, relative to CD, the BP decreased and BSFC increased due to the low calorific value of BD. Regarding exhaust emissions, the $\mathrm{CO}$ and $\mathrm{HC}$ emissions of heated fuel, ultrasonically irradiated fuel, and untreated fuel decreased relative to $\mathrm{CD}$, and the heated fuel showed the best exhaust emissions performance.

The results of this study verified that when animal and vegetable oil blended BD is used as a fuel for agricultural engines, the high viscosity problem of $\mathrm{BD}$ can be solved, and the $\mathrm{CO}$ and $\mathrm{HC}$ in the exhaust emissions can be decreased by simply installing a fuel heating system without changing the engine structure. However, a technology to reduce $\mathrm{NO}_{\mathrm{x}}$ is required to resolve the increased $\mathrm{NO}_{\mathrm{x}}$.

\section{Nomenclature}

$\begin{array}{ll}\text { BD } & \text { Bio-Diesel } \\ \text { BP } & \text { Brake Power } \\ \text { BSFC } & \text { Brake-Specific Fuel Consumption } \\ \text { CD } & \text { Conventional Diesel } \\ \text { CFPP } & \text { Cold Filter Plugging Point } \\ \text { CO } & \text { Carbon Monoxide } \\ \text { CO }_{2} & \text { Carbon Dioxide } \\ \text { EGR } & \text { Exhaust Gas Recirculation } \\ \text { FAME } & \text { Fatty Acid Methyl Ester } \\ \text { FFA } & \text { Free Fatty Acid } \\ \text { LTC } & \text { Low-Temperature Combustion } \\ \text { NAC } & \text { NOx Adsorber Catalyst } \\ \text { NaOH } & \text { Sodium Hydroxide } \\ \text { PM } & \text { Particulate Matter } \\ \text { SCR } & \text { Selective Catalytic Reduction } \\ \text { SFA } & \text { Saturated Fatty Acid } \\ \text { SMD } & \text { Sauter Mean Diameter } \\ \text { SO } & \text { Soybean } \\ \text { TASO } & \text { blended oil of tallow and soybean oil } \\ \text { TA } & \text { Tallow } \\ \text { TR } & \text { Transesterification Reaction } \\ \text { UFA } & \text { Unsaturated Fatty Acid } \\ \text { NO } & \text { Nitrogen Oxide } \\ \text { HC } & \text { Hydrocarbon } \\ & \end{array}$

\section{Acknowledgment}

This work was supported by the Korea Institute of Planning and Evaluation for Technology (IPET) in Food, Agriculture, Forestry, and Fisheries through the Agriculture, Food and Rural Affairs Research Center Support Program, funded by the Ministry of
Agriculture, Food, and Rural Affairs (MAFRA)(716001-7).

\section{Author Contributions}

D.-G.W. (Post-doctoral researcher) conducted the experiments and wrote the manuscript.

T.-H.K. (Professor) led the overall research as a corresponding author and helped revised the manuscript.

\section{References}

1. Escobar JC, Lora ES, Venturini OJ, Yáñez EE, Castillo EF, Almazan O. Biofuels: Environment, technology and food security. Renew. Sust. Energ. Rev. 2009;13:1275-1287.

2. Karmakar A, Biswas PK, Mukherjee S. Environment-congenial biodiesel production from non-edible neem oil. Environ. Eng. Res. 2012;17:S27-S32.

3. Dermibas A. Biodiesel production from vegetable oils via catalytic and non-catalytic supercritical methanol transesterification methods. Prog. Energ. Combust. 2005;31:466-487.

4. Leung DYC, Wu X, Leung MKH. A review on biodiesel production using catalyzed transesterification. Appl. Energ. 2010;87:1083-1095.

5. Gerpen JV. Biodiesel processing and production. Fuel Process. Technol. 2005;86:1097-1107.

6. Kirubakaran M, Selvan VAM. A comprehensive review of low cost biodiesel production from waste chicken fat. Renew. Sust. Energ. Rev. 2018;82:390-401.

7. Zhang Y, Dubé MA, McLean DD, Kates M. Biodiesel production from waste cooking oil: 1. Process design and technological assessment. Bioresour. Technol. 2003;89:1-16.

8. Corré WJ, Conijn JG, Meesters KPH, Bos HL. Accounting for co-products in energy use, greenhouse gas emission savings and land use of biodiesel production from vegetable oils. Ind. Crops Prod. 2016;80:220-227.

9. Pereira GG, Garcia RKA, Ferreira LL, Barrera-Arellano D. Soybean and soybean/beef-tallow biodiesel: A comparative study on oxidative degradation during long-term storage. J. Am. Oil Chem. Soc. 2017;94:587-593.

10. Sajid Z, Khan F, Zhang Y. Process simulation and life cycle analysis of biodiesel production. Renew. Energ. 2016;85:945-952.

11. Renzaho AMN, Kamara JK, Toole M. Biofuel production and its impact on food security in low and middle income countries: Implications for the post-2015 sustainable development goals. Renew. Sust. Energ. Rev. 2017;78:503-516.

12. Leung DYC, Guo Y. Transesterification of neat and used frying oil: Optimization for biodiesel production. Fuel Process. Technol. 2006;87:883-890.

13. Haas MJ, McAloon AJ, Yee WC, Foglia TA. A process model to estimate biodiesel production costs. Bioresour. Technol. 2006;97:671-678.

14. Zhang Y, Dubé MA, McLean DD, Kates M. Biodiesel production from waste cooking oil: 2. Economic assessment and sensitivity analysis. Bioresour. Technol. 2003;90:229-240.

15. Banković-Ilić IB, Stojković IJ, Stamenković OS, Veljkovic VB, 
Hung YT. Waste animal fats as feedstocks for biodiesel production. Renew. Sust. Energ. Rev. 2014;32:238-254.

16. Wang Y, Ma S, Zhao M, Kuang L, Nie J, Riley WW. Improving the cold flow properties of biodiesel from waste cooking oil by surfactants and detergent fractionation. Fuel 2011;90:1036-1040.

17. Cunha MED, Krause LC, Moraes MSA, Faccini CS, Jacques RA, Almeida SR, Rodrigues MRA, Caramão EB. Beef tallow biodiesel produced in a pilot scale. Fuel Process. Technol. 2009;90:570-575.

18. Atabani AE, Silitonga AS, Ong HC, et al. Non-edible vegetable oils: A critical evaluation of oil extraction, fatty acid compositions, biodiesel production, characteristics, engine performance and emissions production. Renew. Sust. Energ. Rev. 2013;18: 211-245.

19. Adewale P, Dumont MJ, Ngadi M. Recent trends of biodiesel production from animal fat wastes and associated production techniques. Renew. Sust. Energ. Rev. 2015;45:574-588.

20. Giakoumis EG, Sarakatsanis CK. Estimation of biodiesel cetane number, density, kinematic viscosity and heating values from its fatty acid weight composition. Fuel 2018;222:574-585.

21. Ramos MJ, Fernández CM, A Casas, Rodríguez L, Pérez Á. Influence of fatty acid composition of raw materials on biodiesel properties. Bioresour. Technol. 2009;100:261-268.

22. Wyatt VT, Hess MA, Dunn RO, Foglia TA, Haas MJ, Marmer WN. Fuel properties and nitrogen oxide emission levels of biodiesel produced from animal fats. J. Am. Oil Chem. Soc. 2005;82:585-591.

23. Goodrum JW, Geller DP, Adams TT. Rheological characterization of animal fats and their mixtures with \#2 fuel oil. Biomass Bioenerg. 2003;24:249-256.

24. Bhuiya MMK, Rasul MG, Khan MMK, Ashwath N, Azad AK, Hazrat MA. Prospects of 2nd generation biodiesel as a sustainable fuel-Part 2: Properties, performance and emission characteristics. Renew. Sust. Energ. Rev. 2016;55: 1129-1146.

25. Dwivedi G, Sharma MP. Impact of cold flow properties of biodiesel on engine performance. Renew. Sust. Energ. Rev. 2014;31:650-656.

26. Öner C, Altun S. Biodiesel production from inedible animal tallow and an experimental investigation of its use as alternative fuel in a direct injection diesel engine. Appl. Energ. 2009;86: 2114-2120.

27. Agarwal D, Kumar L, Agarwal AK. Performance evaluation of a vegetable oil fuelled compression ignition engine. Renew. Energ. 2008;33:1147-1156.

28. Hoang AT, Nguyen VT. Emission characteristics of a diesel engine fuelled with preheated vegetable oil and Biodiesel. Philipp. J. Sci. 2017;146:475-482.

29. Isioma N, Muhammad Y, Innocent D, Linus O. Cold flow properties and kinematic viscosity of biodiesel. Univers. J. Chem. 2013;1:135-141.

30. Smith PC, Ngothai Y, Nguyen QD, O'Neill BK. Improving the low-temperature properties of biodiesel: Methods and consequences. Renew. Energ. 2010;35:1145-1151.

31. Ming TC, Ramli N, Lye OT, Said M, Kasim Z. Strategies for decreasing the pour point and cloud point of palm oil products. Eur. J. Lipid Sci. Technol. 2005;107:505-512.

32. Im SY, Song YS, Ryu JI. Experimental study of the physical and chemical characteristics of biodiesel blended fuel using ultrasonic energy irradiation. Int. J. Automot. Technol. 2008;9: 249-256.

33. Galle J, Defruyt S, Maele CV, et al Experimental investigation concerning the influence of fuel type and properties on the injection and atomization of liquid biofuels in an optical combustion chamber. Biomass Bioenerg. 2013;57:215-228.

34. Yoon SH, Park SH, Lee CS. Experimental investigation on the fuel properties of biodiesel and its blends at various temperatures. Energ. Fuels. 2008;22:652-656.

35. Du E, Cai L, Huang K, Tang H, Xu X, Tao R. Reducing viscosity to promote biodiesel for energy security and improve combustion efficiency. Fuel 2018;211:194-196.

36. Sivalakshmi S, Balusamy T. Effect of biodiesel and its blends with diethyl ether on the combustion, performance and emissions from a diesel engine. Fuel 2013;106:106-110.

37. Labeckas G, Slavinskas S. The effect of rapeseed oil methyl ester on direct injection diesel engine performance and exhaust emissions. Energ. Convers. Manage. 2006;47:1954-1967.

38. Chen H, Wang J, Shuai S, Chen W. Study of oxygenated biomass fuel blends on a diesel engine. Fuel 2008;87:3462-3468.

39. Shi X, Pang X, Mu Y, et al . Emission reduction potential of using ethanol-biodiesel-diesel fuel blend on a heavy-duty diesel engine. Atmos. Environ. 2006;40:2567-2574.

40. Barabás I, Todoruţ A, Băldean D. Performance and emission characteristics of a CI engine fueled with diesel-biodiesel-bioethanol blends. Fue. 2010;89:3827-3832.

41. Yahya A, Marley SJ. Physical and chemical characterization of methyl soyoil and methyl tallow esters as CI engine fuels. Biomass Bioenergy. 1994;6:321-328.

42. Tubino M, Junior JGR, Bauerfeldt GF. Biodiesel synthesis with alkaline catalysts: a new refractometric monitoring and kinetic study. Fuel 2014;125:164-172.

43. Tomasevic AV, Siler-Marinkovic SS. Methanolysis of used frying oil. Fuel Process. Technol. 2003;81:1-6.

44. Freedman B, Pryde EH, Mounts TL. Variables affecting the yields of fatty esters from transesterified vegetable oils. J. Am. Oil Chem. Soc. 1984;61:1638-1643.

45. Akhihiero ET, Oghenejoboh KM, Umukoro PO. Effects of process variables on transesterification reaction of jatropha curcas seed oil for the production of biodiesel. Int. J. Energ. Technol. Adv. Eng. 2013;3:388-393.

46. Alptekin E, Canakci M. Determination of the density and the viscosities of biodiesel-diesel fuel blends. Renew. Energ. 2008;12:2623-2630.

47. Ma FR, Clements LD, Hanna MA. The effects of catalyst, free fatty acids, and water on transesterification of beef tallow. Trans. ASABE. 1998;41:1261-1264.

48. Canakci M, Gerpen JV. Biodiesel production from oils and fats with high free fatty acids. Trans. ASAE. 2001;44:1429-1436.

49. Kleinberg MN, Rios MAS, Buarque HLB, Parente MMV, CavalcanteJr CL, Luna FMT. Influence of synthetic and natural antioxidants on the oxidation stability of beef tallow before biodiesel production. Waste Biomass Valori. 2019;10:797-803.

50. Moraes MSA, Krause LC, Cunha ME, et al. Tallow biodiesel: Properties evaluation and consumption tests in a diesel engine. Energ. Fuel. 2008;22:1949-1954. 
51. Demirbas A. Biodiesel from waste cooking oil via base-catalytic and supercritical methanol transesterification. Energ. Convers. Manage. 2009;50:923-927.

52. Ma F, Hanna MA. Biodiesel production: a review. Bioresour. Technol. 1999;70:1-15.

53. Teixeira LSG, Assis JCR, Mendonça DR. Comparison between conventional and ultrasonic preparation of beef tallow biodiesel. Fuel Process. Technol. 2009;90:1164-1166.

54. Zhang D. Crystallization characteristics and fuel properties of tallow methyl esters [dissertation]. Nebraska: Univ. of Nebraska; 1994.

55. Barat JCJ, Palameri N, Cavallaro S. Biodiesel science and technology from soil to oil. 1st ed. Woodhead Publishing Limited and CRC press; 2010. p.234-295.

56. Encinar JM, Gonzalez JF, Rodriguez JJ, Tejedor A. Biodiesel fuels from vegetable oils: transesterification of cynara cardunculus L. oils with ethanol. Energ. Fuel. 2002;16:443-450.

57. Meher LC, Sagar DV, Naik SN.Technical aspects of biodiesel production by transesterification-a review. Renew. Sust. Energ. Rev. 2006;10:248-268.

58. Knothe G. Dependence of biodiesel fuel properties on the structure of fatty acid alkyl esters. Fuel Process. Technol. 2005;86: 1059-1070.

59. Ding J, He B, Li J. Biodiesel production from acidified oils via supercritical methanol. Energies 2011;4:2212-2223.

60. Hoekman SK, Broch A, Robbins C, Ceniceros E, Natarajan M. Review of biodiesel composition, properties and specifications. Renew. Sust. Energ. Rev. 2012;16:143-169.

61. Srivastava A, Prasad R. Triglycerides-based diesel fuels. Renew. Sust. Energ. Rev. 2004;4:111-133.

62. Ali Y, Hanna MA, Cuppett SL. Fuel properties of tallow and soybean oil esters. J. Am. Oil Chem. Soc. 1995;72:1557-1564.

63. Fadhil AB. Biodiesel production from beef tallow using alkali-catalyzed transesterification. Arab. J. Sci. Eng. 2013;38:41-47.

64. Mata TM, Cardoso N, Ornelas M, Neves S, Caetano NS. Evaluation of two purification methods of biodiesel from beef tallow, pork lard, and chicken fat. Energ. Fuel. 2011;25: 4756-4762.

65. Mata TM, Cardoso N, Ornelas M, Neves S, Caetano NS. Sustainable production of biodiesel from tallow, lard and poultry fat and its quality evaluation. Chem. Eng. Trans. 2010;19:13-18.

66. Knothe G, Matheaus AC, Ryan III TW. Cetane numbers of branched and straight-chain fatty esters determined in an ignition quality tester. Fuel 2003;82:971-975.

67. Verduzco LFR, Rodríguez, JER Jacob ARJ. Predicting cetane number, kinematic viscosity, density and higher heating value of biodiesel from its fatty acid methyl ester composition. Fuel 2012;91:102-111.

68. Lin R, Zhu Y, Tavlarides LL. Effect of thermal decomposition on biodiesel viscosity and cold flow property. Fuel 2014;17: 981-988.

69. Hoekman SK, Broch A, Robbins C, Ceniceros E, Natarajan M. Review of biodiesel composition, properties, and specifications. Rene. Sust. Energ. Rev. 2012;16:143-169.

70. Knothe G, Sharp CA, Ryan TW. Exhaust emissions of biodiesel, petrodiesel, neat methyl esters, and alkanes in a new technology engine. Energ. Fuel. 2006;20:403-408.
71. Gülüm M, Bilgin A. Two-term power models for estimating kinematic viscosities of different biodiesel-diesel fuel blends. Fuel Process. Technol. 2016;149:121-130.

72. Yuan W, Hansen AC, Zhang Q. Predicting the temperature dependent viscosity of biodiesel fuels. Fuel 2009;88:1120-1128.

73. Manh DV, Chen YH, Chang CC, Chang CY, Minh CV, Hanh $\mathrm{HD}$. Parameter evaluation of biodiesel production from unblended and blended Tung oils via ultrasound-assisted process. J. Taiwan Inst. Chem. Eng. 2012;43:368-373.

74. Zareh P, Zare AA, Ghobadian B. Comparative assessment of performance and emission characteristics of castor, coconut and waste cooking based biodiesel as fuel in a diesel engine. Energy 2017;139:883-894.

75. Raheman H, Phadatare AG. Diesel engine emissions and performance from blends of karanja methyl ester and diesel, Biomass Bioenerg. 2004;27 393-397.

76. Usta N, Öztürk E, Can Ö, Conkur ES, Nas S, Çon AH, Can AÇ, Topcu M. Combustion of biodiesel fuel produced from hazelnut soapstock/waste sunflower oil mixture in diesel engine. Energ. Convers. Manag. 2005:46:741-755.

77. Utlu Z, Koçak MS. The effect of biodiesel fuel obtained from waste frying oil on direct injection diesel engine performance and exhaust emissions. Renew. Energ. 2008:33:1936-1941.

78. Ejim CE, Fleck BA, Amirfazli A. Analytical study for atomization of biodiesels and their blends in a typical injector Surface tension and viscosity effects. Fuel 2007;86:1534-1544.

79. An H, Yang WM, Chou SK, Chua KJ. Combustion and emissions characteristics of diesel engine fueled by biodiesel at partial load conditions. Appl. Energ. 2012;99:363-371.

80. Özener O, Yüksek L, Ergenç AT, Özkan M. Effects of soybean biodiesel on a DI diesel engine performance, emission and combustion characteristics. Fuel 2014;115:875-883.

81. Tesfa B, Mishra R, Zhang C, Gu F, Ball AD. Combustion and performance characteristics of CI (compression ignition) engine running with biodiesel. Energy 2013;51:101-115.

82. Aydin H, Bayindir H. Performance and emission analysis of cottonseed oil methyl ester in a diesel engine. Renew. Energ. 2010;35:588-592.

83. Monyem A, Gerpen JHV. The effect of biodiesel oxidation on engine performance and emissions. Biomass Bioenerg. 2001;20: 317-325.

84. Xue J, Grift TE, Hansen AC. Effect of biodiesel on engine performances and emissions. Renew. Sust. Energ. Rev. 2011;15:1098-1116.

85. Hansen AC, Gratton MR, Yuan W. Diesel engine performance and $\mathrm{NO}_{\mathrm{x}}$ emissions from oxygenated biofuels and blends with diesel fuel. Trans. Am. Soc. Agric. Eng. 2006;49:589-595.

86. Shahabuddin M, Liaquat AM, Masjuki HH, Kalam MA, Mofijur M. Ignition delay, combustion and emission characteristics of diesel engine fueled with biodiesel. Renew. Sust. Energ. Rev. 2013;21:623-632.

87. Lee CS, Park SW, Kwon SI. An experimental study on the atomization and combustion characteristics of biodiesel-blended fuels. Energ. Fuel. 2005;19:2201-2208.

88. Banapurmatha NR, Tewaria PG, Hosmath RS. Performance and emission characteristics of a DI compression ignition engine operated on honge, jatropha and sesame oil methyl esters. Renew. Energ. 2008:33:1982-1988. 
89. Qi DH, Chen H, Geng LM, Bian YZH. Experimental studies on the combustion characteristics and performance of a direct injection engine fueled with biodiesel/diesel blends. Energ. Convers. Manag. 2010;51:2985-2992.

90. Selim MYE. Reducing the viscosity of jojoba methyl ester diesel fuel and effects on diesel engine performance and roughness. Energy Convers. Manage. 2009;50(7):1781-1788.

91. Altaie MAH, Janius RB, Rashid U, et al. Performance and exhaust emission characteristics of direct-injection diesel engine fueled with enriched biodiesel. Energ. Convers. Manag. 2015;106: 365-372.

92. Lin CY, Lin HA. Diesel engine performance and emission characteristics of biodiesel produced by the peroxidation process. Fuel 2006;85:298-305.

93. Chauhan BS, Kumar N, Jun YD, Lee KB. Performance and emission study of preheated Jatropha oil on medium capacity diesel engine. Energy 2010;35:2484-2492.

94. Liaquat AM, Masjuki HH, Kalam MA, et al. Effect of coconut biodiesel blended fuels on engine performance and emission characteristics. Procedia Eng. 2013;56:583-590.

95. Rathinam S, Justin Abraham Baby S, Devarajan Y, Arunkumar T. Influence of water on exhaust emissions on unmodified diesel engine propelled with biodiesel. Energ. Sour. Part A Recov. Util. Environ. Eff. 2018;40:2511-2517.

96. Kashdan J, Mendez S, Bruneaux G. An investigation of unburned hydrocarbon emissions in wall guided, low temperature diesel combustion. Oil Gas Sci. Texhnol. 2008;63:433-459.

97. Lin BF, Huang JH, Huang DY. Experimental study of the effects of vegetable oil methyl ester on DI diesel engine performance characteristics and pollutant emissions. Fuel 2009;88:1779-1785.

98. Li L, Wang J, Wang Z, Xiao J. Combustion and emission characteristics of diesel engine fueled with diesel/biodiesel/pentanol fuel blends. Fuel 2015;156:211-218.

99. Rashed MM, Kalam MA, Masjuki HH, Mofijur M, Rasul MG, Zulkifli NWM. Performance and emission characteristics of a diesel engine fueled with palm, jatropha, and moringa oil methyl ester. Ind. Crops Prod. 2016;79:70-76.

100. Lin CY, Li RJ. Engine performance and emission characteristics of marine fish-oil biodiesel produced from the discarded parts of marine fish. Fuel Process. Technol. 2009;90:883-888.
101. Kivevele TT, Kristóf L, Bereczky Á, Mbarawa MM. Engine performance, exhaust emissions and combustion characteristics of a CI engine fueled with croton megalocarpus methyl ester with antioxidant. Fuel 2011;90:2782-2789.

102. Raheman H, Phadatare AG. Diesel engine emissions and performance from blends of karanja methyl ester and diesel. Biomass Bioenergy. 2004;27:393-397.

103. Hoekman SK, Robbins C. Review of the effects of biodiesel on $\mathrm{NO}_{\mathrm{x}}$ emissions. Fuel Process. Technol. 2012:96:237-249.

104. Zheng M, Mulenga MC, Reader GT, Wang MP, Ting DSK, Tjong J. Biodiesel engine performance and emissions in low temperature combustion. Fuel 2008:87:714-722.

105. Thornton MJ, Alleman TL, Luecke J, McCormick RL. Impacts of biodiesel fuel blends oil dilution on light-duty diesel engine operation. SAE Int. J. Fuel. Lubr. 2009:2:781-788.

106. Al-Widyan M, Tashtoush G, Abu-Qudais M. Utilization of ethyl ester of waste vegetable oils as fuel in diesel engines. Fuel Process. Technol. 2002;76:91-103.

107. Ramadhas AS, Muraleedharan C, Jayaraj S. Performance and emission evaluation of a diesel engine fueled with methyl esters of rubber seed oil. Renew. Energ. 2005;30:1789-1800.

108. Xue J, Grift TE, Hansen AC. Effect of biodiesel on engine performances and emissions. Renewable Sustainable Energy Rev. 2011;15:1098-1116.

109. Frijters PJM, Baert RSG. Oxygenated fuels for clean heavy-duty engines. Int. J. Veh. Des. 2006:41:242-255.

110. Armas O, Yehliu K, Boehman AL. Effect of alternative fuels on exhaust emissions during diesel engine operation with matched combustion phasing. Fuel 2010;89:438-456.

111. Luo Y, Zhu L, Fang J, et al. Size distribution, chemical composition and oxidation reactivity of particulate matter from gasoline direct injection (GDI) engine fueled with ethanol-gasoline fuel. Appl. Therm. Eng. 2015;89:647-655.

112. Shameer PM, Ramesh K. Green technology and performance consequences of an eco-friendly substance on a 4-stroke diesel engine at standard injection timing and compression ratio. J. Mech. Sci. Tech. 2017;31:1497-507.

113. Woo DG, Kim TH. Pretreatment methods to improve the kinematic viscosity of biodiesel for use in power tiller engines. J. Mech. Sci. Technol. 2019;33:3655-664. 